Check for updates

Cite this: RSC Adv., 2019, 9, 29936

Received 16th July 2019

Accepted 9th September 2019

DOI: $10.1039 / c 9 r a 05432 d$

rsc.li/rsc-advances

\section{Silver sulfide nanoparticles for photodynamic therapy of human lymphoma cells via disruption of energy metabolism}

\begin{abstract}
Ge Wang, ${ }^{\text {ab }}$ Jing Liu, ${ }^{a}$ Lin Zhu, ${ }^{a}$ Yuming Guo (D) *a and Lin Yang (D) *a
Recently, studies on the application of light-responsive semiconductor nanomaterials for photodynamic therapy (PDT) of non-solid tumors have attracted tremendous attention. Herein, $6.98 \mathrm{~nm}_{\mathrm{Ag}_{2} \mathrm{~S}}$ nanoparticles ( $\mathrm{Ag}_{2} \mathrm{~S} \mathrm{NPs}$ ) with excellent aqueous dispersibility, stability, and biocompatibility were synthesized by a facile strategy without any post-modification. In vitro studies indicated that $\mathrm{Ag}_{2} \mathrm{~S} N P \mathrm{~s}$ could significantly inhibit the growth of human lymphoma cells (Raji cells) compared with hepatoma carcinoma cells (Hep G2 cells) under light irradiation. Further studies revealed that $\mathrm{Ag}_{2} \mathrm{~S} N \mathrm{NP}$ could specifically induce the accumulation of intracellular reactive oxidative species in Raji cells under light irradiation, and induce significant disruption of energy metabolism. This finding provides inspiration for the potential application of $\mathrm{Ag}_{2} \mathrm{~S}$ semiconductor nanoparticles as a photosensitizer to significantly and specifically treat human lymphoma through PDT.
\end{abstract}

\section{Introduction}

Photodynamic therapy (PDT) is known as a non-invasive therapeutic method for efficient treatment of cancers ${ }^{1,2}$ due to its repeatability without cumulative toxicity, minimal invasiveness, and improved quality of life for the patient..$^{3-5}$ Owing to the critical role of photosensitizers in PDT treatment, there is much interest in exploiting superior photosensitizers to enhance the curative duration of PDT. ${ }^{6,7}$ Although traditional organic photosensitizer molecules, such as rhodamine, porphyrin, and their derivatives, ensure effective execution of PDT, ${ }^{8,9}$ some properties still need to be improved: for example, enhanced retention times or resistance to photobleaching. ${ }^{10,11}$ In addition, complicated synthesis and functionalization steps can be barriers to their practical application.

Some inorganic nanomaterials possess intrinsic photodynamic properties for killing tumor cells by photochemical reactions, which are similar to organic photosensitizers, through their inherent light-absorption abilities. ${ }^{12,13}$ Different from organic photosensitizers, the enhanced permeability and retention of inorganic nanomaterials may offer better opportunities for phototherapy applications. ${ }^{14,15}$ However, most studies on inorganic photosensitizers have mainly focused on organic-inorganic hybrid nanomaterials ${ }^{\mathbf{8}, 16,17}$ and upconversion of nanoparticles, ${ }^{18,19}$ which have to overcome

${ }^{a}$ Henan Key Laboratory of Green Chemical Media and Reactions, School of Chemistry and Chemical Engineering, Henan Normal University, Xinxiang, Henan 453007, P. R. China.E-mail: yanglin1819@163.com

${ }^{b}$ School of Basic Medical Sciences, Xinxiang Medical University, Xinxiang, Henan 453003, P. R. China complicated syntheses for energy conversion efficiency. Recently, some semiconductor nanoparticles (SCNPs) with superior photosensitive properties have been used for photodynamic therapy, ${ }^{20}$ including Cd- and Pb-based SCNPs, because they emit in the visible and near-infrared region. ${ }^{20,21}$ However, the high toxicity of lead and cadmium hinders their potential application. Moreover, the lack of in-depth understanding of the response of SCNPs to PDT does not help in their effective use in correlative nanomaterials for PDT. Thus, it is urgent to explore alternative inorganic photosensitizers with low toxicity and improved efficiency.

Some studies have indicated that, due to the absence of toxic metal ions and the ultralow solubility product constant $\left(K_{\mathrm{sp}}=\right.$ $\left.6.3 \times 10^{-50}\right), \mathrm{Ag}_{2} \mathrm{~S}$ exhibits excellent biocompatibility ${ }^{22}$ and a wide range of applications in many fields, including bioimaging, ${ }^{23}$ fluorescent detection of molecules and metal ions ${ }^{24,25}$ electronics, catalysis ${ }^{26}$ and energy conversion. ${ }^{27}$ In particular, $\mathrm{Ag}_{2} \mathrm{~S}$ NPs have attracted increasing attention as a result of their fascinating optical properties. However, little is known about the application of $\mathrm{Ag}_{2} \mathrm{~S}$ nanoparticles $\left(\mathrm{Ag}_{2} \mathrm{~S}\right.$ NPs) as a photosensitizer for PDT, especially to treat non-solid tumors such as lymphoma, which is more aggressive and chemoresistant than solid tumors. ${ }^{28}$

Based on these considerations and using bovine serum albumin (BSA) as stabilizer, we utilize a facile strategy to synthesize crystalline $\mathrm{Ag}_{2} \mathrm{~S}$ nanoparticles with good water dispersibility. The as-prepared $\mathrm{Ag}_{2} \mathrm{~S}$ NPs can be used directly as a photosensitizer to significantly inhibit the growth of human lymphoma cells under light irradiation. This can be ascribed to accumulation of intracellular reactive oxygen species (ROS) and the corresponding disruption of energy metabolism. The results 
indicate that $\mathrm{Ag}_{2} \mathrm{~S}$ NPs might be used as a photosensitizer to specifically and significantly treat human lymphoma through PDT.

\section{Experimental section}

\section{Chemicals}

Silver nitrate $\left(\mathrm{AgNO}_{3}\right)$, thioacetamide (TAA), and BSA were purchased from Sigma Chemical Co. (USA). Reactive oxygen species assay kit was purchased from Beyotime Biotechnology (Shanghai, China). Fetal bovine serum (FBS), EMEM medium, DMEM medium, trypsin, 3-(4,5-dimethylthiazol-2-yl)-2,5diphenyltetrazolium bromide (MTT), and annexin V-FITC/PI double-staining assay kit were purchased from Becton Dickinson and Company.

\section{Preparation of $\mathrm{Ag}_{2} \mathrm{~S} / \mathrm{BSA}$ NPs}

$\mathrm{AgNO}_{3}$ was dissolved in double-distilled water $\left(\mathrm{ddH}_{2} \mathrm{O}\right)$ and mixed with BSA solution, then moderately stirred for $6 \mathrm{~h}$ to ensure complete chelation of $\mathrm{Ag}^{+}$with BSA. Then, TAA was dissolved in $\mathrm{ddH}_{2} \mathrm{O}$ and slowly injected into the $\mathrm{Ag}^{+}-\mathrm{BSA}$ mixed solution under nitrogen flow, then allowed to stand for $24 \mathrm{~h}$ at $25{ }^{\circ} \mathrm{C}$. Finally, the sample $\left(\mathrm{Ag}_{2} \mathrm{~S} / \mathrm{BSA} \mathrm{NPs}\right)$ was collected and dried under vacuum.

\section{Characterization}

The morphology and size of the $\mathrm{Ag}_{2} \mathrm{~S}$ NPs were characterized by HRTEM (JEOL JEM-2100). The Fourier transform infrared (FTIR) spectra were recorded in the range 4000-400 $\mathrm{cm}^{-1}$ (BioRad FTS-40 FT-IR spectrometer). The crystal phase of the $\mathrm{Ag}_{2} \mathrm{~S}$ /BSA NPs was determined using an X-ray diffractometer (Bruker AXS, Germany) with graphite-monochromatized $\mathrm{CuK} \alpha$ radiation $(\lambda=0.15406 \mathrm{~nm})$ in the $2 \theta$ range $20-70^{\circ}$. UV-vis absorption spectra were recorded on a Shimadzu UV-1700 spectrometer. Zeta potentials in phosphate buffer solution (PBS), $\mathrm{H}_{2} \mathrm{O}$, serum or DMEM, were measured using a Nano-ZS instrument. Photoluminescence (PL) measurements were carried out on a HITACHI FP-6500 spectrophotometer.

\section{Cell culture and evaluation of cytotoxic effects}

Human hepatoma (Hep G2) and lymphoma (Raji) cells were purchased from the Cell Bank of the Chinese Academy of Sciences, Shanghai, China. The cells were incubated in DMEM or EMEM medium under $5.0 \mathrm{wt} \% / \mathrm{vol} \mathrm{CO}_{2}$ at $37{ }^{\circ} \mathrm{C}$. Then, $\mathrm{Ag}_{2} \mathrm{~S}$ NPs of different concentrations were added. After $2 \mathrm{~h}$ incubation, cells were irradiated with a diode laser $(400-600 \mathrm{~nm}, 0.4 \mathrm{~W}$ $\mathrm{cm}^{-2}, \varnothing 3 \mathrm{~mm}$ ) for $10 \mathrm{~h}$. The cytotoxic effects of $\mathrm{Ag}_{2} \mathrm{~S}$ NPs under dark or light irradiation were determined by MTT cytotoxic assay. ${ }^{29}$ The data were analyzed by one-way ANOVA.

\section{Annexin V-FITC/PI double-staining assay}

Hep G2 cells and Raji cells $\left(1 \times 10^{5}\right.$ cells per $\left.\mathrm{ml}\right)$ were cultured for $24 \mathrm{~h}$. Then, the cells were exposed to $\mathrm{Ag}_{2} \mathrm{~S}$ NPs for $12 \mathrm{~h}$ under dark or light irradiation. As control, cells without treatment with $\mathrm{Ag}_{2} \mathrm{~S}$ NPs were prepared. After treatment, the cells were harvested. The apoptotic and necrotic evaluation was quantified by flow cytometric analysis.

\section{Confocal microscopy analysis}

Hep G2 cells and Raji cells $\left(1 \times 10^{5}\right.$ cells per $\left.\mathrm{ml}\right)$ were incubated in a confocal dish for $12 \mathrm{~h}$. Then, the cells were treated with $\mathrm{Ag}_{2} \mathrm{~S}$ NPs. An FV1200 spectral confocal microscope (Olympus, Japan) was used to image cells in one-photon mode. As control, the untreated cells were imaged.

\section{Evaluation of intracellular internalization of $\mathrm{Ag}_{2} \mathrm{~S}$ NPs}

Hep G2 cells and Raji cells $\left(1 \times 10^{5}\right.$ cells per $\left.\mathrm{ml}\right)$ were treated by $\mathrm{Ag}_{2} \mathrm{~S}$ NPs for $12 \mathrm{~h}$ under dark or light irradiation. Subsequently, all of the cells were continually exposed under dark for $6 \mathrm{~h}$. After treatment, the cells were digested with concentrated nitric acid for $2 \mathrm{~h}$. As control, the cells without treatment with $\mathrm{Ag}_{2} \mathrm{~S}$ NPs were prepared. Then, the intracellular concentrations of $\mathrm{Ag}^{+}$ were analyzed by inductively coupled plasma-mass spectroscopy (ICP-MS) (ELAN DRC-e, PerkinElmer SCIEX).

\section{Flow cytometric analysis and confocal microscopy imaging analysis of intracellular ROS}

$2^{\prime}, 7^{\prime}$-Dichlorofluorescin diacetate (DCFH-DA) was utilized to evaluate intracellular ROS levels. Briefly, after incubation with $\mathrm{Ag}_{2} \mathrm{~S}$ NPs for $12 \mathrm{~h}$ under dark or light irradiation, the cells $(1 \times$ $10^{6}$ cells per $\mathrm{ml}$ ) were further exposed to DCFH-DA for $2 \mathrm{~h}$. Subsequently, cells were continually exposed under dark for another $6 \mathrm{~h}$. As control, the cells without treatment with $\mathrm{Ag}_{2} \mathrm{~S}$ NPs were prepared. After treatment, the cells were harvested. The fluorescence of intracellular ROS was analyzed by flow cytometry. Meanwhile, cell imaging was carried out using a FV1200 spectral confocal microscopy.

\section{Photostability of $\mathrm{Ag}_{2} \mathrm{~S}$ NPs}

To evaluate the photostability of the $\mathrm{Ag}_{2} \mathrm{~S}$ NPs, the photoluminescence and UV-vis absorbance of $\mathrm{Ag}_{2} \mathrm{~S}$ NPs were continually monitored every $2 \mathrm{~h}$ under dark or light irradiation.

\section{Glycolysis metabolism evaluation by Seahorse extracellular flux (XF-96) analyzer}

The glycolytic capacity was determined for Raji cells using the Seahorse XF-96 analyzer. Cells were incubated for $24 \mathrm{~h}$ and treated with $\mathrm{Ag}_{2} \mathrm{~S}$ NPs under dark or light irradiation. Then, cellular oxygen consumption rates (OCRs) were measured as follows. Cells were washed with Seahorse assay media supplemented with fresh sodium pyruvate and glucose and incubated at $37{ }^{\circ} \mathrm{C}$ without $\mathrm{CO}_{2}$ for $1 \mathrm{~h}$. Oligomycin $(1 \mu \mathrm{M})$, carbonyl cyanide-p-trifluoromethoxyphenylhydrazone (FCCP) $(0.5 \mu \mathrm{M})$, and rotenone/antimycin $\mathrm{A}(1 \mu \mathrm{M})$ were sequentially added into each well. Then, the amount of oxygen consumption for adenosine triphosphate (ATP) production (coupling efficiency), the level of proton leak (non-ATP-linked oxygen consumption), the maximal respiration capacity, and the level of nonmitochondrial respiration were measured. 


\section{Results and discussion}

Synthesis and characterization of silver sulfide nanoparticles

Silver sulphide nanoparticles ( $\mathrm{Ag}_{2} \mathrm{~S}$ NPs) were synthesized using BSA as a stabilizer by a facile method. First, silver nitrate aqueous solution was gently mixed with BSA aqueous solution to construct the chelating system. Then, the chelating system was mixed with freshly prepared TAA aqueous solution to prepare $\mathrm{Ag}_{2} \mathrm{~S}$ NPs. The X-ray diffraction (XRD) pattern was recorded and used to demonstrate formation of the silver sulfide. The diffraction peaks with $2 \theta$ values at $31.52^{\circ}, 34.38^{\circ}$, and $36.81^{\circ}$ (Fig. 1a) can be indexed to the $(-112),(-121)$ and (121) planes of acanthite $\mathrm{Ag}_{2} \mathrm{~S}$. From the HRTEM images shown in Fig. 1b, the as-prepared $\mathrm{Ag}_{2} \mathrm{~S}$ comprises well-dispersed nanoparticles with an average diameter of $\sim 6.98 \mathrm{~nm}$. The lattice fringe spacing in the HRTEM image was determined as $0.294 \mathrm{~nm}$ (see Fig. 1c), corresponding to the (-112) plane of acanthite $\mathrm{Ag}_{2} \mathrm{~S}$.

The zeta potentials of $\mathrm{Ag}_{2} \mathrm{~S}$ NPs in $\mathrm{ddH}_{2} \mathrm{O}, \mathrm{FBS}, \mathrm{PBS}$, and DMEM medium were determined to be $-24.74,-26.78$, -21.48 , and $-31.21 \mathrm{mV}$, respectively. Therefore, these results reveal the excellent stability of the $\mathrm{Ag}_{2} \mathrm{~S}$ NPs under physiological conditions when the $\mathrm{Ag}_{2} \mathrm{~S}$ NPs are dispersed into different media. The FT-IR spectroscopic analysis results indicate the presence of BSA in the as-prepared $\mathrm{Ag}_{2} \mathrm{~S}$ NPs. From the FT-IR spectra shown in Fig. 2a, compared with $\mathrm{Ag}_{2} \mathrm{~S}$ NPs, absorption bands of $\mathrm{N}-\mathrm{H}$ stretching $\left(3193 \mathrm{~cm}^{-1}\right)$ and amide bands $\left(1662,1539\right.$, and $\left.1399 \mathrm{~cm}^{-1}\right)$ were detected in the
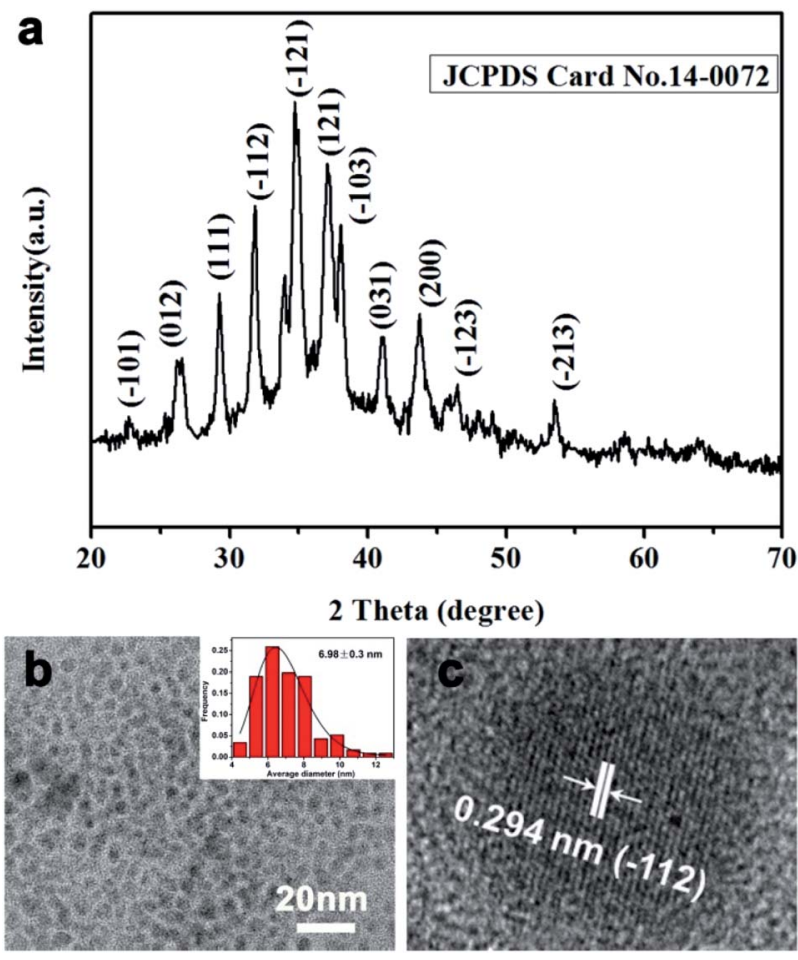

Fig. 1 Characterization of silver sulfide. (a) XRD pattern of silver sulfide. ( $b$ and $c$ ) HRTEM images of silver sulfide and lattice fringe image (c). Inset (b): size distribution analysis.
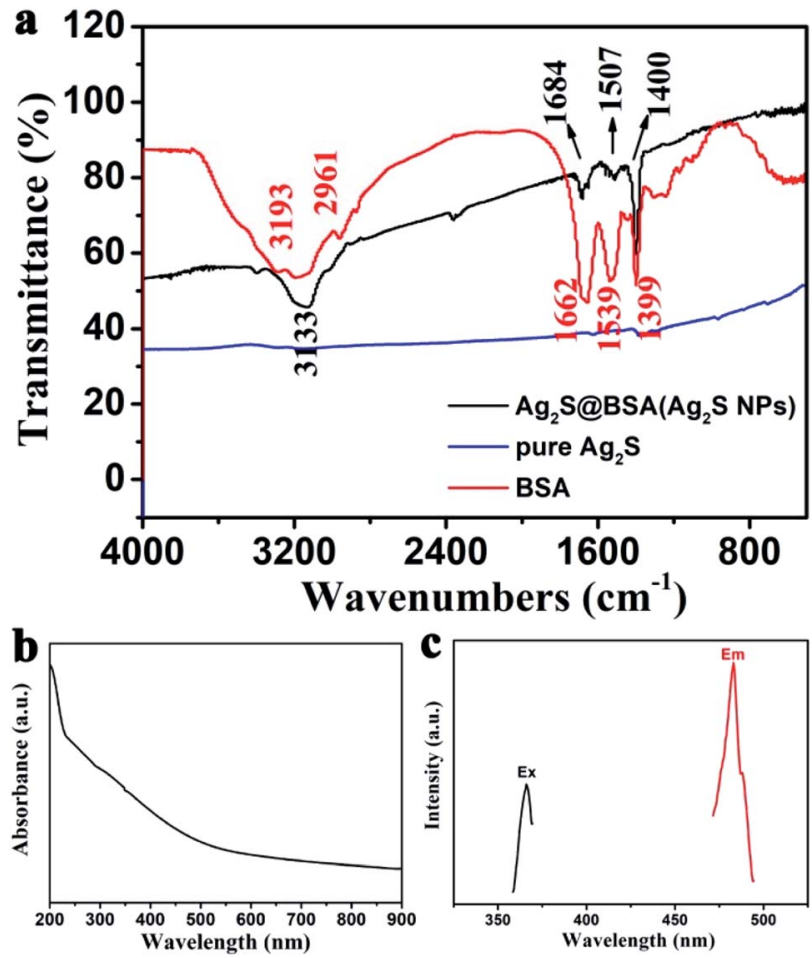

Fig. 2 Optical adsorption and photodynamic properties of $\mathrm{Ag}_{2} \mathrm{~S} N P s$. (a) FT-IR spectra of $\mathrm{Ag}_{2} \mathrm{~S} @ \mathrm{BSSA}\left(\mathrm{Ag}_{2} \mathrm{~S} N P s\right), \mathrm{BSA}$ and pure $\mathrm{Ag}_{2} \mathrm{~S}$. (b) UVvis spectrum of $A_{2} S$ NPs $\left(3.5 \mu \mathrm{g} \mathrm{ml}^{-1}\right)$ in aqueous solutions. (c) Fluorescence spectrum of $\mathrm{Ag}_{2} \mathrm{~S} \mathrm{NPs}\left(3.5 \mu \mathrm{g} \mathrm{ml}^{-1}\right)$ in aqueous solution.

spectrum of BSA. In the spectrum for $\mathrm{Ag}_{2} \mathrm{~S}$ NPs the absorption bands for $\mathrm{N}-\mathrm{H}$ stretching are observed to shift to lower wavenumber (3193 to $3133 \mathrm{~cm}^{-1}$ ) and the amide bands obviously shift to higher/lower wavenumber $(1684,1507$, and $1400 \mathrm{~cm}^{-1}$ ), suggesting the presence of BSA in $\mathrm{Ag}_{2} \mathrm{~S}$ NPs and the interaction of silver sulfide with BSA.

From the ultraviolet-visible (UV-vis) absorption characterization (Fig. 2b), silver sulfide nanoparticles exhibit strong absorbance in the range $200-600 \mathrm{~nm}$, revealing good photo absorption properties. In Fig. 2c, the fluorescence spectrum demonstrates that $\mathrm{Ag}_{2} \mathrm{~S}$ NPs exhibit a powerful emission peak at $483 \mathrm{~nm}$ (excitation wavelength: $366 \mathrm{~nm}$ ).

\section{Cell cytotoxicity assay}

The antiproliferative effects of $\mathrm{Ag}_{2} \mathrm{~S}$ NPs on Hep G2 human hepatocellular carcinoma cells and Raji human lymphoma cells were evaluated under dark or light irradiation using the MTT assay. From the data shown in Fig. $3 \mathrm{a}, \mathrm{Ag}_{2} \mathrm{~S}$ NPs slightly inhibit the proliferation of Hep G2 cells under dark or light irradiation. From Fig. 3b, negligible cytotoxicity was observed when Raji cells were treated with $\mathrm{Ag}_{2} \mathrm{~S}$ NPs in the dark. However, under light irradiation, $\mathrm{Ag}_{2} \mathrm{~S}$ NPs significantly inhibited the proliferation of Raji cells, compared with Hep G2 cells. The results indicate that $\mathrm{Ag}_{2} \mathrm{~S}$ NPs could be used as photosensitizers for PDT of human lymphoma cells, such as Raji cells. 


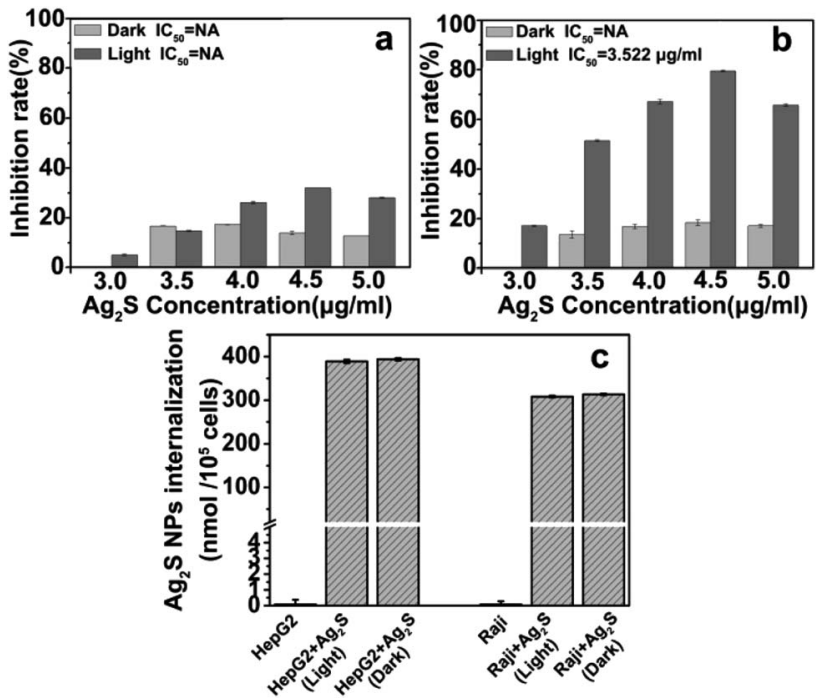

Fig. 3 Proliferative effects of cells studied using the MTT method. (a) Hep G2 cells and (b) Raji cells were treated in cell culture media with silver sulfide under dark and light irradiation for 72 h. (c) ICP-MS analysis of $\mathrm{Ag}_{2} \mathrm{~S}$ NP amounts in Hep G2 and Raji cells under dark or light irradiation. Error bars represent $n=3$.

\section{Cellular internalization of $\mathrm{Ag}_{2} \mathrm{~S}$ NPs}

In order to explore the possible reasons for the specific anticancer activities of $\mathrm{Ag}_{2} \mathrm{~S}$ NPs, the amounts of intracellular nanoparticles internalized by Hep G2 cells and Raji cells were determined through ICP-MS analysis. From the results shown in Fig. 3c, more $\mathrm{Ag}_{2} \mathrm{~S}$ NPs could be internalized by Hep G2 cells. However, the intracellular amounts of $\mathrm{Ag}_{2} \mathrm{~S}$ NPs internalized by Raji cells or Hep G2 cells do not show significant differences under dark or light irradiation. This suggests that the different efficiency for anticancer PDT of $\mathrm{Ag}_{2} \mathrm{~S}$ NPs towards Hep G2 and Raji cells is not derived from the difference in the amounts of internalized nanoparticles. Meanwhile, ICP-MS results indicate that light irradiation cannot increase the amount of $\mathrm{Ag}_{2} \mathrm{~S} \mathrm{NP}$ internalization by Raji cells (Fig. 3c). In addition, the $\mathrm{Ag}_{2} \mathrm{~S}$ NPs cannot be specifically internalized by Raji cells or Hep G2 cells.

Because of the different antiproliferative effects of $\mathrm{Ag}_{2} \mathrm{~S}$ NPs on different cancer cells, the apoptosis-inducing effects of $\mathrm{Ag}_{2} \mathrm{~S}$ NPs on Hep G2 cells and Raji cells were determined using the annexin V-FITC/PI double-staining assay through flow cytometry analysis. From Fig. $4 \mathrm{a}-\mathrm{c}$ it can be seen that the apoptosis of Hep G2 cells cannot be induced by $\mathrm{Ag}_{2} \mathrm{~S}$ NPs, either under dark or light irradiation. Fig. $4 \mathrm{~d}-\mathrm{f}$ shows that $\mathrm{Ag}_{2} \mathrm{~S}$ NPs, also, cannot induce apoptosis and necrosis of Raji cells under dark irradiation. However, $\mathrm{Ag}_{2} \mathrm{~S}$ NPs could significantly induce apoptosis and necrosis $(30 \%)$ of Raji cells under light irradiation. These results suggest that the considerable antiproliferative effects of $\mathrm{Ag}_{2} \mathrm{~S}$ NPs on Raji cells are relevant to apoptosis.

Confocal microscopy images (Fig. 5a) show the luminescence intensity in Raji human lymphoma cells from $\mathrm{Ag}_{2} \mathrm{~S}$ NPs. The bright-field images and overlay of confocal luminescence show that luminescence can be observed in the cytoplasm but not in the membrane surface and nucleus. In Fig. 5b-e, the UV-

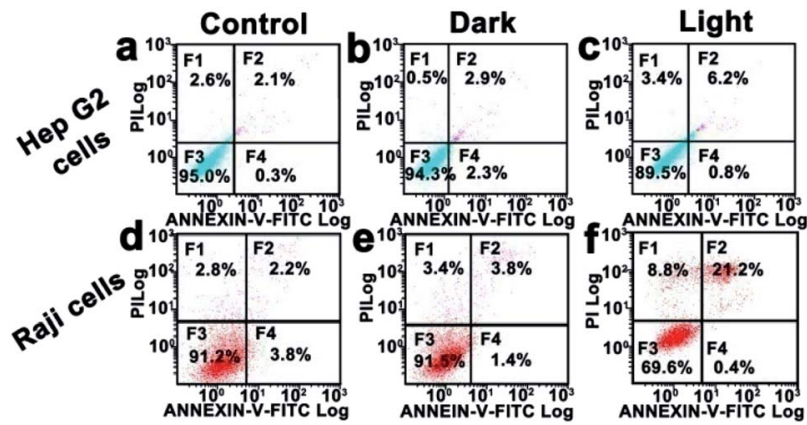

Fig. 4 Percentage of cell viability after treatment with silver sulfide nanoparticles. Flow cytometric analysis of Hep G2 cells: (a) control, (b) treatment under dark, and (c) treatment under light irradiation. Flow cytometric analysis of Raji cells: (d) control, (e) treatment under dark, and (f) treatment under light irradiation.

vis and fluorescence spectra of $\mathrm{Ag}_{2} \mathrm{~S}$ NPs do not show obvious changes when illuminated for different periods of time, revealing their good photostability.

Confocal microscopy images indicate that $\mathrm{Ag}_{2} \mathrm{~S}$ NPs cannot induce generation of intracellular ROS in Hep G2 cells when treated under dark or light irradiation (Fig. 6a-c). For Raji cells, the control cells and the cells treated with $\mathrm{Ag}_{2} \mathrm{~S}$ NPs
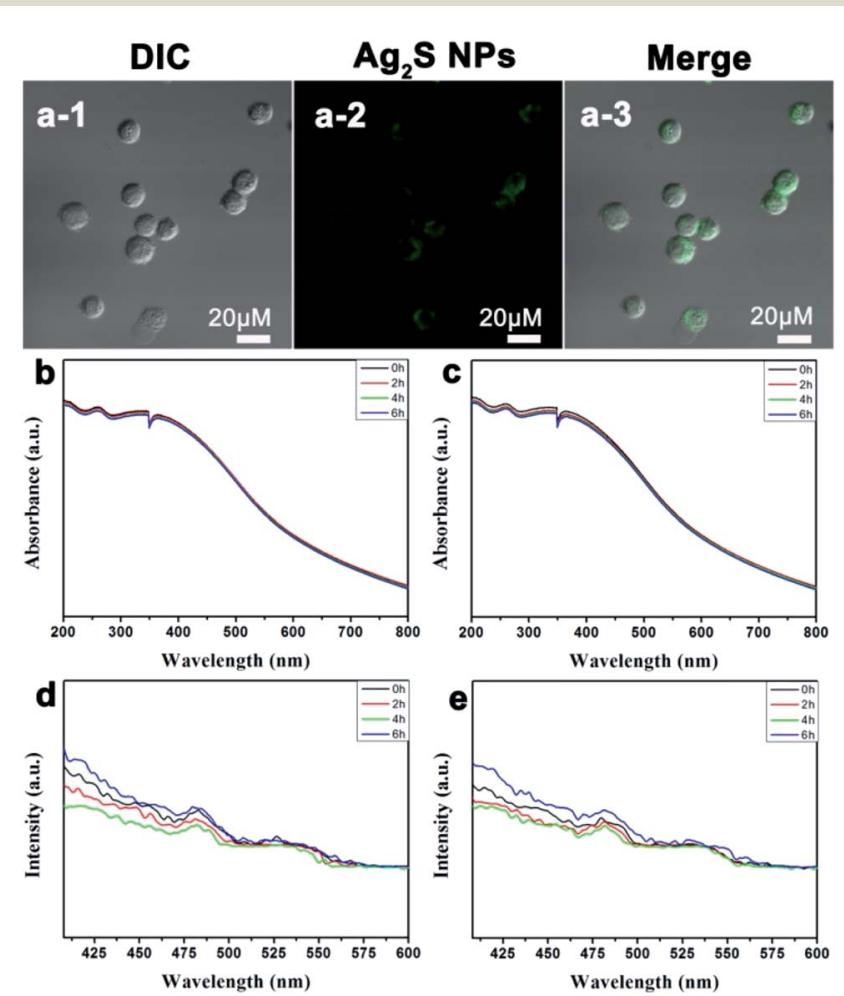

Fig. 5 (a) Confocal microscopy images of Raji cells treated with $\mathrm{Ag}_{2} \mathrm{~S}$ NPs $\left(3.5 \mu \mathrm{g} \mathrm{ml}^{-1}\right)$ in aqueous solution. DIC: differential interference contrast microscope image. (b and c) UV-vis absorption spectra of $\mathrm{Ag}_{2} \mathrm{~S}$ NPs $\left(3.5 \mu \mathrm{g} \mathrm{ml}^{-1}\right)$ in aqueous solutions, dark and illuminated for different periods of time. ( $d$ and e) Photoluminescence spectra of $\mathrm{Ag}_{2} \mathrm{~S}$ NPs (3.5 $\mu \mathrm{g} \mathrm{ml}^{-1}$ ) in aqueous solutions, dark and illuminated for different periods of time. 
DIC

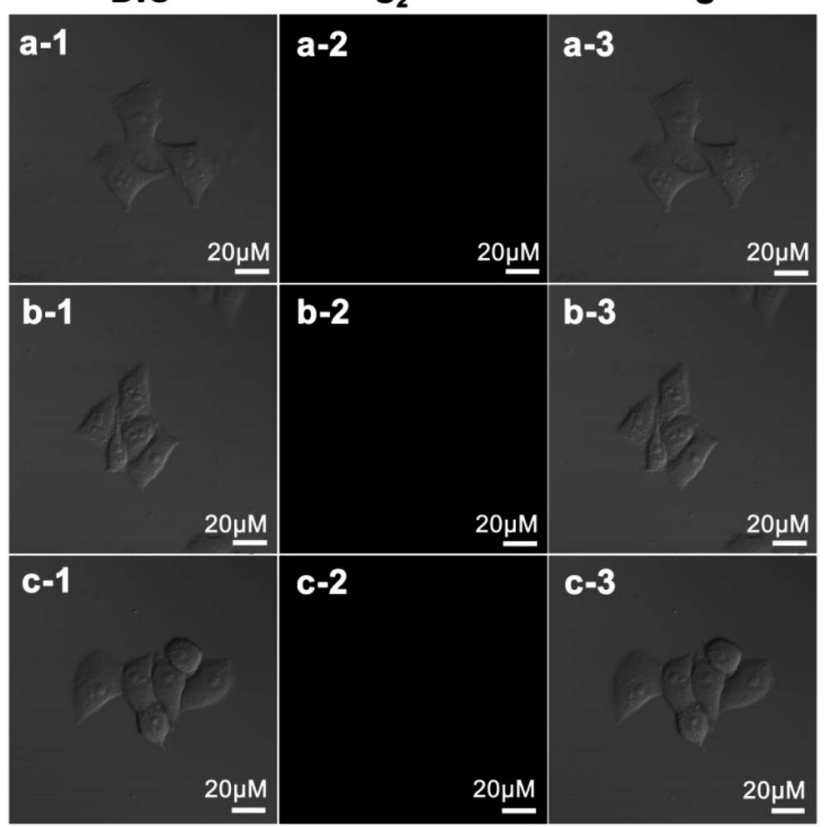

Fig. 6 Confocal microscopy images of Hep G2 cells with DCFH-DA: (a) control cells; (b) Hep G2 cells treated by $\mathrm{Ag}_{2} \mathrm{~S} \mathrm{NPs}\left(3.5 \mu \mathrm{g} \mathrm{ml}^{-1}\right)$ in aqueous solutions under dark; (c) Hep G2 cells treated by $\mathrm{Ag}_{2} \mathrm{~S}$ NPs $\left(3.5 \mu \mathrm{g} \mathrm{ml}^{-1}\right)$ in aqueous solutions under light irradiation.

under dark exhibit only negligible green fluorescence (Fig. 7a and $b$ ). These results suggest that the intracellular level of ROS is very low when cells are treated with $\mathrm{Ag}_{2} \mathrm{~S}$ NPs under dark irradiation. However, in contrast, strong green fluorescence was observed in Raji cells treated with $\mathrm{Ag}_{2} \mathrm{~S}$ NPs under light irradiation (Fig. 7c), revealing the presence of high levels of intracellular ROS. These results indicate that high levels of intracellular ROS can be specifically generated by Raji cells upon treatment with $\mathrm{Ag}_{2} \mathrm{~S}$ NPs under irradiation, which was further quantified by flow cytometric analysis. From Fig. 7d, compared with control cells, the fluorescence level of DCFH from the Raji cells treated with $\mathrm{Ag}_{2} \mathrm{~S}$ NPs under dark does not show strong enhancement. However, after treatment with $\mathrm{Ag}_{2} \mathrm{~S}$ NPs under light irradiation, the fluorescence level from Raji cells increases sharply. This confirms that treatment of Raji cell $\mathrm{Ag}_{2} \mathrm{~S}$ NPs under light illumination can induce generation of intracellular ROS in Raji cells, which is critical for PDT of cancer cells.

To understand the photodynamic response of Raji cells treated with $\mathrm{Ag}_{2} \mathrm{~S}$ NPs in depth, the OCR, an indicator of mitochondrial respiration, was determined to evaluate the effects of different treatments on the mitochondrial function of cancer cells. From the results shown in Fig. 8, compared with untreated Raji cells, the basal respiration, maximal respiration, and spare capacity of Raji cells decreased significantly when treated with $\mathrm{Ag}_{2} \mathrm{~S}$ NPs under light irradiation. However, the cells treated with $\mathrm{Ag}_{2} \mathrm{~S}$ NPs under dark were not influenced. These results reveal that $\mathrm{Ag}_{2} \mathrm{~S}$ NPs under light irradiation could give rise to disruption of energy metabolism.

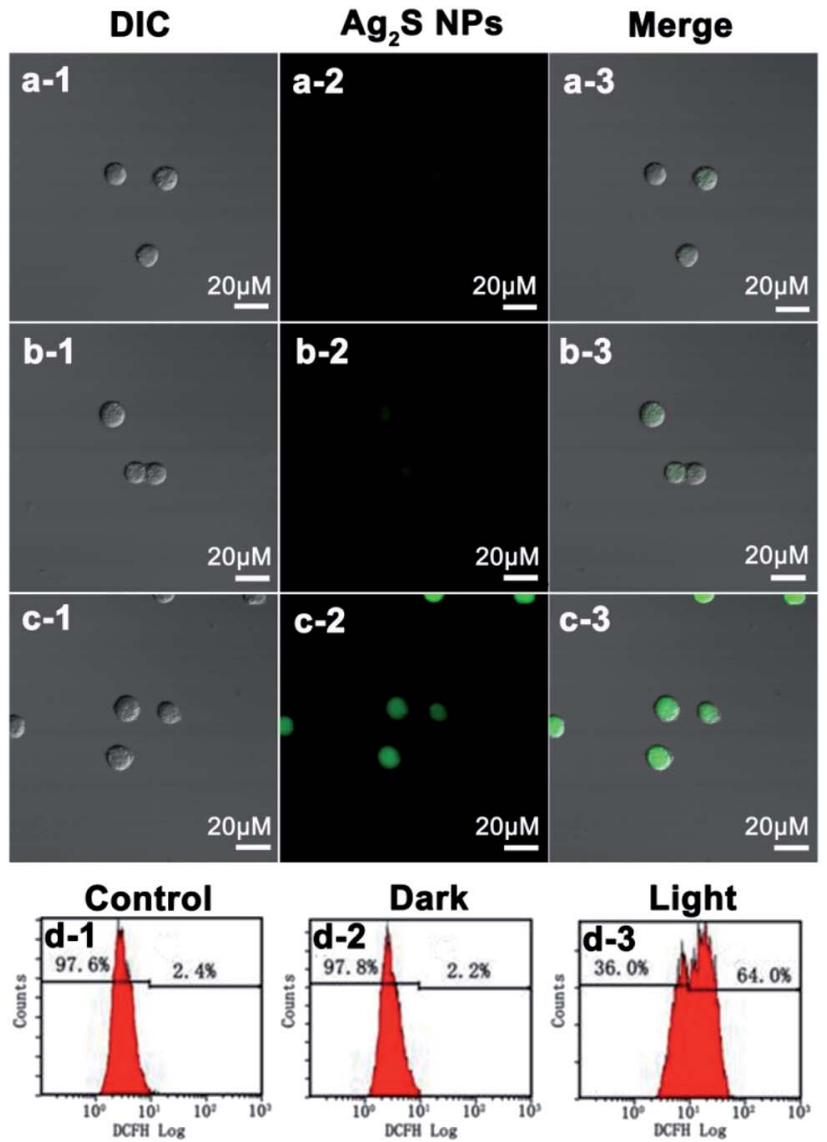

Fig. 7 Confocal microscopy images of Raji cells with DCFH-DA: (a) control cells; (b) treatment by $\mathrm{Ag}_{2} \mathrm{~S} N P s\left(3.5 \mu \mathrm{g} \mathrm{ml}^{-1}\right)$ in aqueous solutions under dark and (c) under light irradiation. (d) Flow cytometric analysis of ROS in Raji cells.

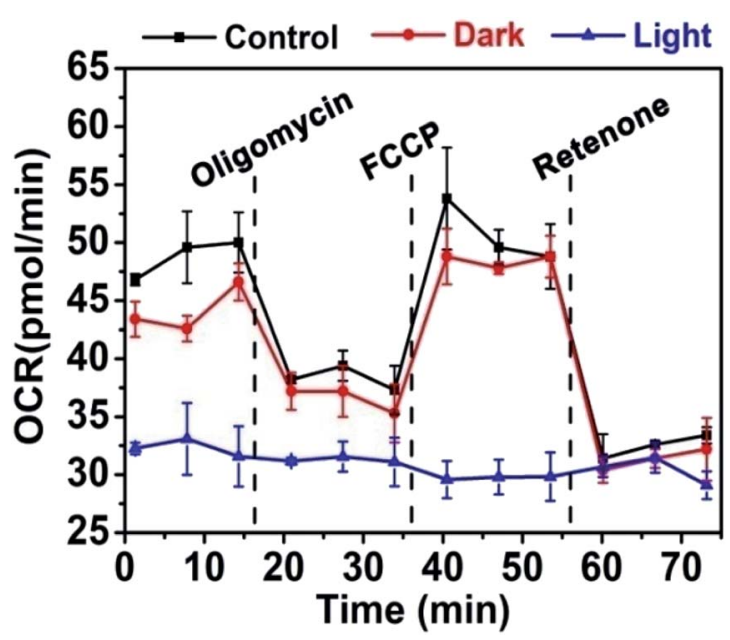

Fig. 8 Cellular OCR of Raji cells by treatment with $\mathrm{Ag}_{2} \mathrm{~S}$ NPs under dark and light irradiation. Error bars represent $n=3$.

\section{Conclusions}

In summary, aiming to find alternatives for inorganic photosensitizers that have low toxicity and improved efficiency as sole 
and direct photosensitizers for PDT, $\mathrm{Ag}_{2} \mathrm{~S} / \mathrm{BSA}$ hybrid nanoparticles with stable water dispersibility were prepared by a facile method, and without complicated modification. The $\mathrm{Ag}_{2} \mathrm{~S}$ NPs with good solubility can be used directly as photosensitizers to significantly inhibit the growth of human nonsolid tumors cells, such as human lymphoma cells, under light irradiation. This can be explained by accumulation of intracellular ROS. Furthermore, this study indicates a mechanism whereby $\mathrm{Ag}_{2} \mathrm{~S}$ NPs damage mitochondrial function and disrupt energy metabolism, which could be used for sole and direct application to photodynamic therapy for human lymphoma cells.

\section{Conflicts of interest}

There are no conflicts to declare.

\section{Acknowledgements}

This work was financially supported by National Natural Science Foundation of China (21571053, 21771058), Program for Science Technology Innovation Talents and Team in Universities of Henan Province (18IRTSTHN002), Key Project of Science and Technology of Henan Province (182102311182), Key Scientific Research Project of Higher Education of Henan Province (18A150046), the 111 project (D17007) and Henan Center for Outstanding Overseas Scientists (GZS2018003).

\section{References}

1 S. Liu, H. Zhang, Y. Li, J. Liu, L. Du, M. Chen, R. T. K. Kwok, J. W. Y. Lam, D. L. Phillips and B. Z. Tang, Angew. Chem., Int. Ed., 2018, 57, 15189-15193.

2 Z. Zhou, J. Song, L. Nie and X. Chen, Chem. Soc. Rev., 2016, 45, 6597-6626.

3 Y. Jiang, X. Pang, R. Liu, Q. Xiao, P. Wang, A. W. Leung, Y. Luan and C. Xu, ACS Appl. Mater. Interfaces, 2018, 10, 31674-31685.

4 M. Chudy, K. Tokarska, E. Jastrzębska, M. Bułka, S. Drozdek, Ł. Lamch, K. A. Wilk and Z. Brzózka, Biosens. Bioelectron., 2018, 101, 37-51.

5 W. Fan, N. Lu, C. Xu, Y. Liu, J. Lin, S. Wang, Z. Shen, Z. Yang, J. Qu, T. Wang, S. Chen, P. Huang and X. Chen, ACS Nano, 2017, 11, 5864-5872.

6 M. H. Chan, Y. T. Pan, I. J. Lee, C. W. Chen, Y. C. Chan, M. Hsiao, F. Wang, L. Sun, X. Chen and R. S. Liu, Small, 2017, 13, 1700038.

7 L. Feng, F. He, Y. Dai, B. Liu, G. Yang, S. Gai, N. Niu, R. Lv, C. Li and P. Yang, ACS Appl. Mater. Interfaces, 2017, 9, 12993-13008.

8 J. Chen, Y. Xu, Y. Gao, D. Yang, F. Wang, L. Zhang, B. Bao and L. Wang, ACS Appl. Mater. Interfaces, 2018, 10, 248-255.
9 K. Hirakawa, D. Ouyang, Y. Ibuki, S. Hirohara, S. Okazaki, E. Kono, N. Kanayama, J. Nakazaki and H. Segawa, Chem. Res. Toxicol., 2018, 31, 371-379.

10 M. Cheng, Y. X. Cui, J. Wang, J. Zhang, L. N. Zhu and D. M. Kong, ACS Appl. Mater. Interfaces, 2019, 11, 1315813167.

11 R. Yang, M. Hou, Y. Gao, L. Zhang, Z. Xu, Y. Kang and P. Xue, Nanoscale, 2019, 11, 5717-5731.

12 L. e. Zhang, L. Zeng, Y. Pan, S. Luo, W. Ren, A. Gong, X. Ma, H. Liang, G. Lu and A. Wu, Biomaterials, 2015, 44, 82-90.

13 J. Y. Zhang, S. Chen, P. Wang, D. J. Jiang, D. X. Ban, N. Z. Zhong, G. C. Jiang, H. Li, Z. Hu, J. R. Xiao, Z. G. Zhang and W. W. Cao, Nanoscale, 2017, 9, 2706-2710.

14 J. E. Au Chang, H. J. Au Cho and S. Au Jheon, J. Visualized Exp., 2016, e54865.

15 L. Li, S. Zhou, N. Lv, Z. Zhen, T. Liu, S. Gao, J. Xie and Q. Ma, Mol. Pharm., 2018, 15, 3595-3599.

16 Y.-X. Zhu, H.-R. Jia, Z. Chen and F.-G. Wu, Nanoscale, 2017, 9, 12874-12884.

17 T. Nomoto, S. Fukushima, M. Kumagai, K. Miyazaki, A. Inoue, P. Mi, Y. Maeda, K. Toh, Y. Matsumoto, Y. Morimoto, A. Kishimura, N. Nishiyama and K. Kataoka, Biomater. Sci., 2016, 4, 826-838.

18 F. Yang, J. Liu, X. Jiang, W. Wu, Z. Wang, Q. Zeng and R. Lv, RSC Adv., 2019, 9, 17273-17280.

19 X. Sun, J. Sun, B. Dong, G. Huang, L. Zhang, W. Zhou, J. Lv, X. Zhang, M. Liu, L. Xu, X. Bai, W. Xu, Y. Yang, X. Song and H. Song, Biomaterials, 2019, 201, 42-52.

20 J. Sun, Y. Guo, L. Zhu, L. Yang, W. Shi, K. Wang and H. Zhang, Part. Part. Syst. Charact., 2017, 34, 1600413.

21 K. Huang, L. Chen, J. Deng and J. Xiong, J. Nanomater., 2012, 2012, 1-12.

22 R. Gui, A. Wan, X. Liu, W. Yuan and H. Jin, Nanoscale, 2014, 6, 5467-5473.

23 X. Jia, D. Li, J. Li and E. Wang, RSC Adv., 2015, 5, 8092980932.

24 F. Nemati and R. Zare-Dorabei, Talanta, 2019, 200, 249-255.

25 P. Jiang, S. Li, M. Han, Y. Liu and Z. Chen, Analyst, 2019, 144, 2604-2610.

26 Y. Chen, Y. Liang, M. Zhao, Y. Wang, L. Zhang, Y. Jiang, G. Wang, P. Zou, J. Zeng and Y. Zhang, Ind. Eng. Chem. Res., 2019, 58, 3538-3548.

27 Z. Qiu, J. Shu and D. Tang, Anal. Chem., 2018, 90, 1221412220.

28 M. Ahmed, E. Lorence, J. Wang, D. Jung, L. Zhang, K. Nomie and M. Wang, Sci. Signaling, 2019, 12, eaat4105.

29 C. Abshire, H. Y. Murad, J. S. Arora, J. Liu, S. H. Mandava, V. T. John, D. B. Khismatullin and B. R. Lee, J. Pharm. Sci., 2017, 106, 1355-1362. 